\title{
Use of participatory mapping approaches for activity space studies: a brief overview of pros and cons
}

\author{
Kamyar Hasanzadeh
}

Accepted: 11 August 2021 / Published online: 20 August 2021

(C) The Author(s) 2021

\begin{abstract}
Participatory mapping approaches have raised increasing interest in a variety of fields of research and practice during the past two decades. However, their use in modeling and studying individual mobility and activity spaces is rather recent and limited. This paper focuses on the use of public participation GIS (PPGIS) data in activity space modeling and analysis and aims to draw more scholarly attention to the existing research potentials in this area. While reviewing the pros of using PPGIS for activity space studies, this paper also discusses the existing limitations and outlines how they can be addressed in future research. PPGIS effectively enables collecting data from larger samples, making it possible to conduct more comprehensive geospatial and statistical analyses on the data. Additionally, the strong link between individuals and places in PPGIS data facilitates more person-based approaches in investigating person-environment relationships. However, use of PPGIS for activity space studies comes with analytical and data quality challenges that need to be thoroughly taken into consideration. Particularly, future research needs to seek new ways of including the temporal dimension in PPGIS and find new methods of using the data for activity space modeling and analysis.
\end{abstract}

K. Hasanzadeh $(\bowtie)$

Department of Built Environment, Aalto University, PO Box 14100, 00076 Aalto, Finland

e-mail: kamyar.hasanzadeh@aalto.fi
Keywords PPGIS - Activity space - Mobility · Participatory mapping · Survey · GIS · Modeling · Spatial analysis

\section{Introduction}

Not long ago, papers dealing with geographic information science (GIS) had to start by introducing the concept and elucidating its many features and advantages. Today, GIS has changed from being a luxury to being a readily available necessity, and it has become an indisputable part of the mainstream in many areas of research and practice. During the course of this rapid evolution, GIS research has also broadened significantly, and purely technical issues have given way to research on the implementation of technology (Obermeyer, 1998). More recently, societal issues have increasingly become important subjects in GIS research. Among the societal issues, concerns related to collective community decision-making, and democracy have sparked research interest in self-reported participatory mapping approaches such as public participation GIS (PPGIS).

At the same time, over recent decades, GIS has increasingly been used in fields such as urban planning, environmental health promotion, and transportation studies to study human experience and behavior in urban environments. To realize such research goals, 
new concepts and GIS methods have emerged to facilitate the study of multilevel and complex humanenvironment interactions. One of these concepts that was given a new life in this frenzy of environmental research is activity space. Activity space refers to a space containing a set of geographically distributed points that are visited by an individual (Reynolds, 1971). Activity spaces have been increasingly used in environmental research both to serve as a spatial unit of analysis for areal GIS calculations and as a measure of mobility and environmental exposure (Hasanzadeh, 2019a).

Activity spaces are meant to capture individuals' whereabouts in space but can even consider time. Obviously, this cannot be accomplished without an individual-based spatial dataset. A simple example of such a dataset is one that includes an individual's everyday important places such as home, workplace, etc., and everyday travel routes. Such data for mapping activity spaces have been acquired from a variety of sources. While activity spaces were traditionally mapped using global positioning systems (GPS) and mobile phone tracking data, the difficulties and limitations associated with acquiring such rich spatial data have given rise to the use of other alternative data collection methods, such as PPGIS, for such spatial modeling activities (Smith et al., 2021).

Although methods such as PPGIS are not free from limitations, they offer advantages that are worth considering and discussing. Nevertheless, there have been only a few studies to date using PPGIS for activity space modeling, and there is little discussion on the usability of such methods for activity space studies. Motivated by this gap, this paper focuses on the use of PPGIS data in activity space modeling and discusses the pros and cons of using self-reported approaches for individual-based studies. Following a review of the concepts and the relevant scholarly endeavors, this paper builds its discussion based on existing experiences and aims to draw more attention to the potential and risks involved in the use of participatory mapping approaches in studies examining activity spaces. This study predominantly focuses on the use of PPGIS data in activity space studies, as there are other studies where the pros and cons of PPGIS as a method of data collection and a means of public participation in planning are more broadly discussed (Babelon et al., 2017; Brown \& Fagerholm, 2015; Brown \& Kyttä, 2018).

\section{Public participation GIS}

PPGIS originally began in the field of urban planning, where the use of public participation methods for spatial planning has a longer history (Obermeyer, 1998). PPGIS is meant to bring the academic practices of GIS and mapping to the local level to empower people, including marginalized populations, in the public arena (Schuurman, 2004). Participatory mapping approaches applied in various fields in research and practice have increasingly grown in popularity around the world over the past two decades. These approaches have been called by different names but are predominantly referred to as PPGIS (Brown \& Kyttä, 2014). PPGIS generates spatial information for a variety of urban, regional, and environmental applications (Schlossberg \& Shuford, 2005); it seeks to understand location-specific human values, perceptions, behavior, and preferences for future land use and development (Fagerholm et al., 2021). To achieve this, PPGIS employs and enriches a wide range of spatial and visual tools, such as sketch maps, digital maps, and satellite imagery, to enhance the geographic involvement of people. In plain words, PPGIS is often operationalized through a combination of traditional questionnaires and a mapping component (Fig. 1). For the questionnaires, theme-specific information is queried, while in the mapping components, participants are asked to map features on a map and usually to provide additional information for each mapping. Accordingly, each mapping feature is usually accompanied by additional geocoded attribute data about the place. Currently, these surveys are commonly in digital format; however, they can be implemented through other media as well.

PPGIS has been extensively used in environmental and urban research to study different themes, for example, social sustainability (Kyttä et al., 2015a, 2015b), residential preferences and dissonance (Hasanzadeh et al., 2019a, 2019b; Kajosaari et al., 2019a), active living and health promotion (Laatikainen et al., 2019), ecosystem service and landscape values (Torralba et al., 2018), and marine and coastal planning (Munro et al., 2017). PPGIS has also been used in the context of accessibility research and travel behavior (Czepkiewicz et al., 2018; Laatikainen et al., 2015). 


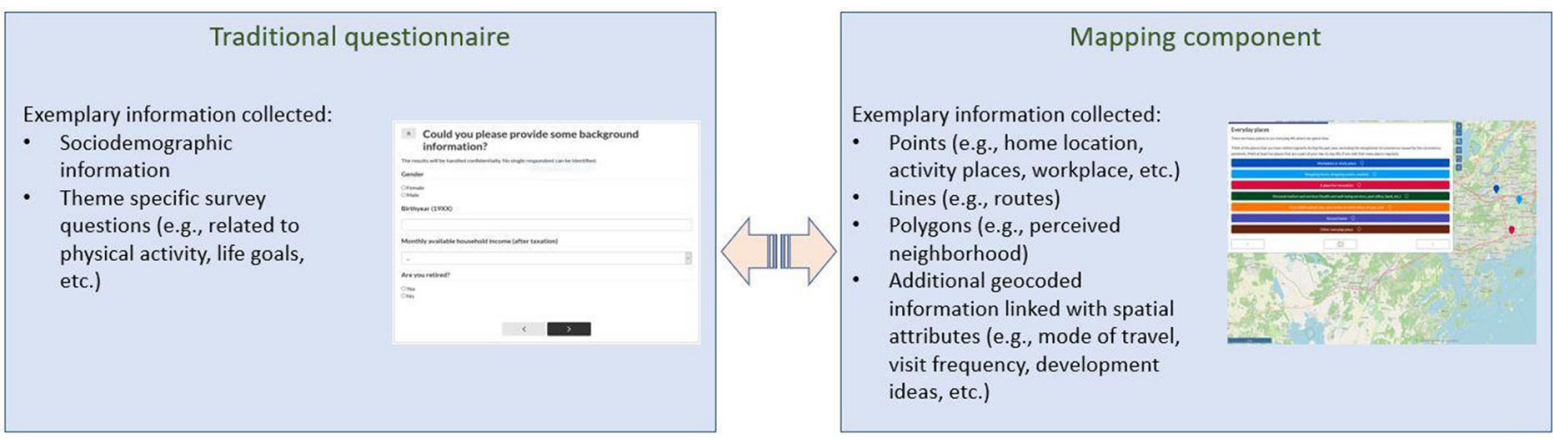

Fig. 1 Structure of a typical PPGIS survey

While the majority of these studies focus on an origindestination comparison (Haybatollahi et al., 2015) or simply report the use of travel modes (Broberg \& Sarjala, 2015), few have attempted to measure actual mobility and assess its implications for different aspects of everyday life (Hasanzadeh et al., 2019a; Laatikainen et al., 2018; Perchoux et al., 2014; Saadallah, 2020).

Activity space: definition and applications

When studying human behavior in space or analyzing human-environment relationships, researchers have found it particularly convenient to use spatial containers for GIS analyses. These containers, or socalled spatial units of analysis, are often mapped as geometries of various complexity enclosing all or part of the spatial features of interest (Hasanzadeh et al., 2017a), but they can also be raster data resulting from more complex GIS operations (Chainey et al., 2008; Wei et al., 2018). Regardless of how these units are operationalized, the idea behind their use is simple: to capture the geographical extent and narrow down the area of analysis for measuring relevant quantities. These units are called by different names depending on the relevant discipline and research purpose. However, 'activity space' has perhaps been the most frequently used umbrella term for this concept.

The term 'activity space' first emerged in zoology to map animal territories (Burt, 1943). Soon after, it was adopted by social scientists for a similar purpose, but for humans (Reynolds, 1971). Since then, activity spaces have been commonly used as spatial units measuring individual mobility and to examine how people's habitual movements interact with their environment (Sherman et al., 2005a). Studying human activity spaces can yield useful insights into many phenomena related to humans' living experience and facilitate our understanding of human behavior and its relationship with the built environment ( $\mathrm{Xu}$ et al., 2016). For example, activity spaces have been used to study the associations between the built environment and mental health (Vallée et al., 2011), obesity (Zenk et al., 2011), travel mode choice (Pesola et al., 2020; Ramezani et al., 2019), residential dissonance (Hasanzadeh et al., 2019a, 2019b; Kajosaari et al., 2019a), and segregation (Wong \& Shaw, 2011).

\section{Modeling activity spaces}

In geography, activity spaces are commonly defined as a set of geographical areas in which people move or travel during the course of their daily activities (Gesler $\&$ Albert, 2003). Technically speaking, these sets can be represented as delineated spaces. As elaborately reviewed in a number of studies (Hasanzadeh, 2019a; Smith et al., 2021), the range of methods used for delineation, i.e., for modeling, these spaces are very wide and diverse (see examples in Fig. 2). While uniformly applied buffers provide an easy individualbased solution (Boone-Heinonen \& Gordon-Larsen, 2011), more complex geometries such as networkbased buffers, standard deviational ellipses, and convex hulls take the modeling a step further and offer a more individual-specific activity space definition (Mavoa et al., 2019; Sherman et al., 2005a; Villanueva et al., 2012). Some approaches go even further and argue that activity spaces are unique to individuals in not only their shape and geometry but also their very fabric (Hasanzadeh et al., 2018; Wang et al., 2018). This view argues that activity spaces vary not only from person to person but also from place to 

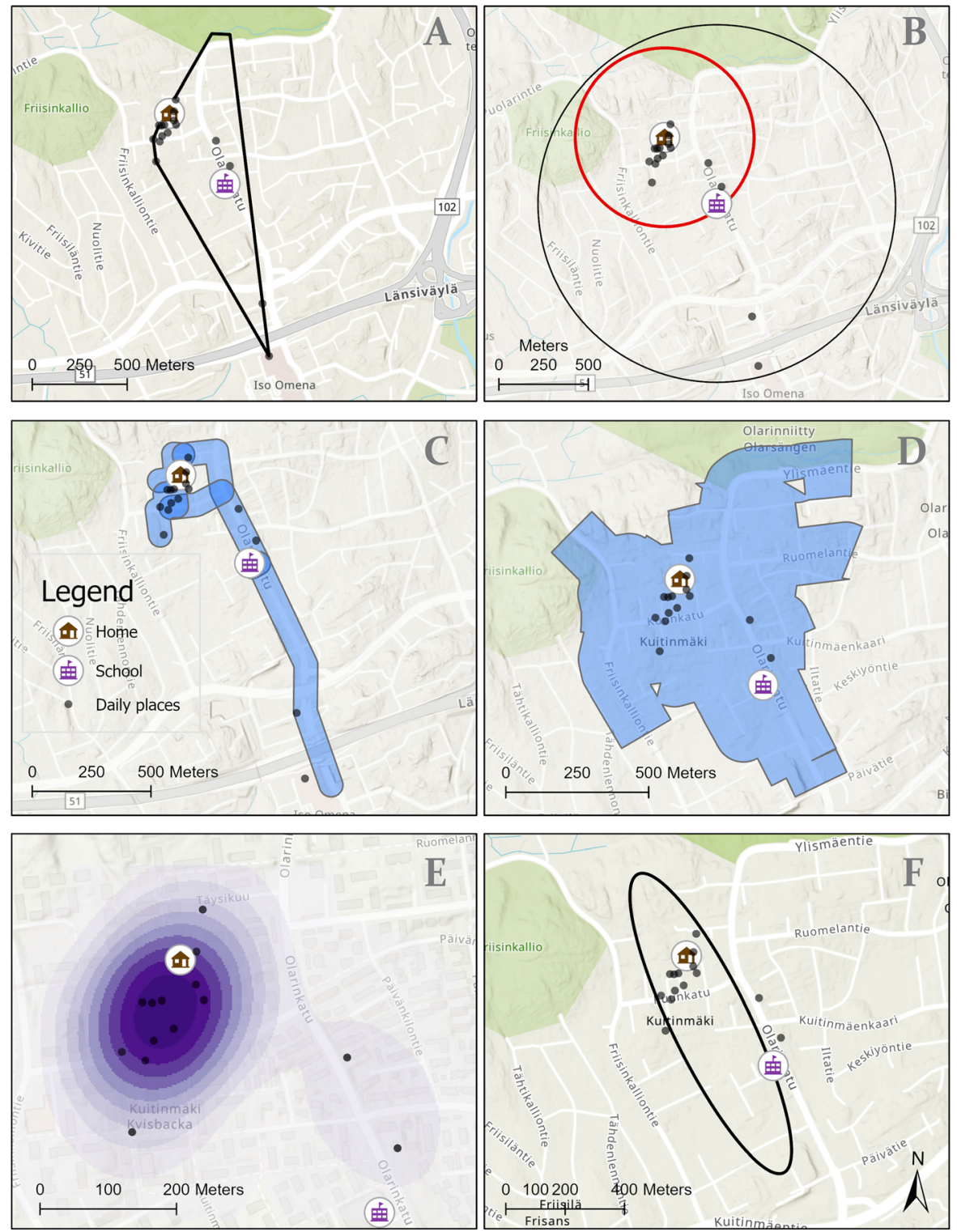

Fig. 2 Illustrative example of methods employed to map activity spaces. A Convex hull B Circular buffer 500 and $1000 \mathrm{~m}$ C Route buffer D Home-based network distance buffer E Kernel density F Standard deviational ellipse

place, as not all locations are of equal significance to an individual. Therefore, an activity space can be better represented as raster (Hasanzadeh et al., 2018). This raster provides a pixel-by-pixel estimation of place exposure (Matthews, 2011) and can range in complexity from a simple kernel density (Kestens et al., 2010) to a distance decay-based exposure estimation (Hasanzadeh et al., 2018) to a crystalgrowth algorithm-based estimation of exposures (Wang et al., 2018).
Despite all the diversity in how activity spaces are perceived, modeled, and represented, most approaches have certain elements in common, such as different information on the geographical whereabouts of the individuals and the various characteristics of their mobility behavior. Table 1 categorizes these common elements into three groups of must know, should know, and good to know based on their frequency of use in the literature and their centrality to the definition of activity space models. 
Table 1 A categorization of elements is often required for activity space modeling

\begin{tabular}{|c|c|c|c|}
\hline Category & Data & Format & Exemplary methods \\
\hline $\begin{array}{l}\text { Must } \\
\text { know }\end{array}$ & Home location & Spatial: Point & Home buffers (Kyttä et al., 2015a, 2015b; Perchoux et al., 2016) \\
\hline \multirow[t]{2}{*}{$\begin{array}{l}\text { Should } \\
\text { know }\end{array}$} & $\begin{array}{l}\text { Destinations, i.e., } \\
\text { activity points }\end{array}$ & Spatial: Point & $\begin{array}{l}\text { Minimum convex polygon (Buliung \& Kanaroglou, 2006), standard } \\
\text { deviational ellipse (Saadallah, 2020) }\end{array}$ \\
\hline & Travel routes & $\begin{array}{l}\text { Spatial: Polyline } \\
\text { or points }\end{array}$ & Shortest path network (Schönfelder \& Axhausen, 2003) \\
\hline \multirow[t]{3}{*}{$\begin{array}{l}\text { Good to } \\
\text { know }\end{array}$} & Travel mode & Nominal & $\begin{array}{l}\text { Individualized residential exposure model (IREM) (Laatikainen et al., } \\
\text { 2018) }\end{array}$ \\
\hline & Type of destination & Nominal & Home range (Hasanzadeh et al., 2019) \\
\hline & Travel frequency & $\begin{array}{l}\text { Numeric or } \\
\text { ordinal }\end{array}$ & $\begin{array}{l}\text { Individualized residential exposure model (IREM) (Hasanzadeh et al., } \\
\text { 2018) }\end{array}$ \\
\hline
\end{tabular}

For the model to be individual based, a bare minimum of information comprising an individual's center of activities is needed. This "must know" information is often operationalized as the exact or approximate home location. Such information is often central to the definition of an activity space, and by itself can suffice to create the simplest representation of an activity space such as a home-based buffer. Other "should know" elements often include information on the typical destinations and routes of individuals to capture the spatial extent of activity spaces. Additionally, other elements can be included in an activity space model that may not necessarily affect the physical characteristics of the activity space but that add information on the intensity and other qualities related to the activities. Although less commonly used in the activity space literature, these "good to know" elements can help construct more comprehensive, and possibly more complex, models of activity spaces.

It should be noted that in theory, an activity space model created based on a wider range of such elements can provide a more refined picture of an individual's mobility and spatial whereabouts. In practice, however, not all these elements, i.e., data, are available or even necessary for every research need. Furthermore, a richer data-driven model will not necessarily result in a more informative model, as how these elements are integrated into a model plays a crucial role in how usable or informative the model is.

Activity spaces have been predominantly created based on datasets collected through GPS (Hirsch et al., 2014; Kestens et al., 2018). The choice of GPS as a data collection method has advantages that make it an obvious choice for many environmental researchers, as it can collect dense and accurate spatial data on an individual level. Nevertheless, the use of this conventional spatial data collection method also poses some challenges. Individual-level GPS data can be expensive and time-consuming to collect. Moreover, the GPS data used in activity space studies are often coupled with parallel travel diaries filled by participants to capture actual experiences (Mavoa et al., 2011; J. Wolf et al., 2001). Working with such diaries is a laborious task, and analyzing them quantitatively is not always feasible (Nguyen et al., 2017). Such difficulties have led some researchers to look elsewhere for individual-level spatial data collection.

Alternatively, some researchers have used mobile phone tracking data to map individual activity spaces (Chen et al., 2018; González et al., 2008; Xu et al., 2016). While such datasets can be easier to acquire in some countries, they can raise privacy concerns. Additionally, mobile phone tracking data cannot capture the actual experience of the individuals studied (Harari, 2020). More rarely, attempts have been made to incorporate big data in modeling individual activity spaces (Huang \& Wong, 2015). However, such datasets are not reliable resources in regard to mapping individual activity spaces, as geolocations can be inaccurate, misleading, and inconsistent (Jagadish et al., 2014). Furthermore, big data collected from social media may not adequately represent all sociodemographic groups in a population (Buelens et al., 2014). 


\section{Materials and methods}

This paper builds a discussion around the pros and cons of using PPGIS data in studies examining activity spaces based on the limited experience in this area. The studies reviewed in this paper cover topics ranging from research on promoting environmental health to mobility studies where activity space has been used whether as a spatial unit of analysis or a means of measuring individual mobility. The selected papers reviewed in this paper were chosen from studies that operationalized activity spaces as geometric entities in Euclidean space using geospatial analytical and modeling methods. Studies were queried using different combinations and variations of keywords, including PPGIS, activity space, individual mobility, and action space.

\section{Use of PPGIS data for modeling activity spaces}

A good starting point to discuss the usability of PPGIS data for activity space mapping is to review the specific data requirements for such mapping activities. Modeling activity spaces requires individual-level data on people's geographical whereabouts and mobility behavior. However, these are rarely sufficient for an empirical research study. Activity spaces are seldom mapped as the ultimate goal of a study but more commonly as a means of exploring humanenvironment associations. Thus, while locational data are required to map activity spaces, they rarely suffice to answer all research questions in a study. For example, mobility and activity space characteristics are often studied in relation to other personal characteristics (Perchoux et al., 2014; Ramezani et al., 2021), in many studies to look for possible associations between personal characteristics and spatial patterns (Hasanzadeh, 2019b). Most often, some personal variables are also needed as control variables to adjust for personal effects. A common example of this is the use of sociodemographic characteristics as control variables (Perchoux et al., 2014). Additionally, the good-to-know elements, as described in Table 1, require geocoded attribute data to be spatially analyzable.

Such data requirements for adopting individualbased activity spaces in research can be conveniently facilitated through PPGIS methods, such as online map-based surveys. However, this approach has been pursued only in a few research studies thus far (Table 2). A study conducted in Alexandria, Egypt, used a combination of onsite and online map drawing and surveys to map individual activity spaces using the standard deviation ellipse (SDE) method (Saadallah, 2020). In a study done in the Helsinki area in Finland, researchers used data collected through an online mapbased survey known as softGIS to map individual home ranges (Hasanzadeh et al., 2017b). These researchers used home location and everyday errand points to define a custom minimum convex polygon (MCP) representation of individual activity spaces (Hasanzadeh et al., 2017a). The same method with minor modifications was implemented in a number of other studies in several Finnish cities (Kajosaari et al., 2019b, 2020; Ramezani et al., 2019).

Researchers in Helsinki took this idea even further and developed an exposure-based model of activity spaces "represented both as raster and polygon" using PPGIS data (Hasanzadeh et al., 2018; Laatikainen et al., 2018). Exposure in these studies was estimated using information on home locations, everyday errand points, travel routes, travel modes, and travel frequency, all collected using an online map-based survey from a population of older adults in the Helsinki metropolitan area (Gottwald et al., 2016; Hasanzadeh et al., 2018). A similar approach was also proposed in a study protocol aimed at comparing children's activity and independent mobility between two Finnish towns with and without free public transit (Pesola et al., 2020). These studies used an online tool named Maptionnaire to develop map-based surveys (Kahila-Tani et al., 2019).

In a study conducted in the Paris metropolitan area, Perchoux and her colleagues studied the activity spaces of individuals using survey data on regular activity places and residential neighborhoods collected through the VERITAS application (Visualization and Evaluation of Route Itineraries, Travel Destinations, and Activity Spaces) (Perchoux et al., 2014). VERITAS is a web-based interactive mapping questionnaire that, unlike Maptionnaire, requires an administered data collection procedure using face-toface meetings with participants (Chaix et al., 2012). There have also been similar studies using the same tool in other places, such as Montreal and Luxembourg (Kestens et al., 2012; Perchoux et al., 2019). 
Table 2 Summary of studies using PPGIS data for activity space modeling

\begin{tabular}{|c|c|c|c|c|c|}
\hline Study & Area & $\begin{array}{l}\text { Survey } \\
\text { (size) }\end{array}$ & $\begin{array}{l}\text { Model } \\
\text { (format) }\end{array}$ & Data included & Topic of study \\
\hline $\begin{array}{l}\text { (Hasanzadeh } \\
\text { et al., 2017a) }\end{array}$ & HMA & $\begin{array}{l}\text { Online } \\
(3119)\end{array}$ & $\begin{array}{l}\text { Dynamic home } \\
\text { range } \\
\text { (polygon) }\end{array}$ & Home, everyday destinations & $\begin{array}{l}\text { Activity space modeling and } \\
\text { evaluation }\end{array}$ \\
\hline $\begin{array}{l}\text { (Hasanzadeh } \\
\text { et al., 2018) }\end{array}$ & HMA & $\begin{array}{l}\text { Online } \\
(844)\end{array}$ & $\begin{array}{l}\text { IREM } \\
\text { (raster) }\end{array}$ & $\begin{array}{l}\text { Home location, everyday } \\
\text { destinations, travel mode, } \\
\text { travel routes (estimated), } \\
\text { activity types, travel } \\
\text { frequency }\end{array}$ & $\begin{array}{l}\text { Environmental health promotion and } \\
\text { physical activity among older } \\
\text { adults-socioeconomic and urban } \\
\text { structural associations }\end{array}$ \\
\hline $\begin{array}{l}\text { (Saadallah, } \\
\text { 2020) }\end{array}$ & Alexandria & $\begin{array}{l}\text { Paper* } \\
(112)\end{array}$ & $\begin{array}{l}\text { SDE } \\
\text { (polygon) }\end{array}$ & Activity places, activity types & $\begin{array}{l}\text { Environmental health promotion and } \\
\text { physical activity }\end{array}$ \\
\hline $\begin{array}{l}\text { (Kajosaari } \\
\text { et al., 2019a) }\end{array}$ & HMA & $\begin{array}{l}\text { Online } \\
(772)\end{array}$ & $\begin{array}{l}\text { Home range } \\
\text { (polygon) }\end{array}$ & $\begin{array}{l}\text { Home location, everyday } \\
\text { destinations }\end{array}$ & Residential dissonance \\
\hline $\begin{array}{l}\text { (Kajosaari } \\
\text { et al., 2020) }\end{array}$ & Tampere & $\begin{array}{l}\text { Online } \\
(900)\end{array}$ & $\begin{array}{l}\text { Home range } \\
\text { (polygon) }\end{array}$ & $\begin{array}{l}\text { Home location, everyday } \\
\text { destinations }\end{array}$ & $\begin{array}{l}\text { Effects of residential location and } \\
\text { stated residential preferences on } \\
\text { activity space characteristics }\end{array}$ \\
\hline \multirow[t]{3}{*}{$\begin{array}{l}\text { (Ramezani } \\
\text { et al., 2019) }\end{array}$} & \multirow[t]{3}{*}{ HMA } & \multirow[t]{3}{*}{$\begin{array}{l}\text { Online } \\
(844)\end{array}$} & $\begin{array}{l}\text { Home range } \\
\text { (polygon) }\end{array}$ & $\begin{array}{l}\text { Home location, everyday } \\
\text { destinations }\end{array}$ & \multirow[t]{3}{*}{$\begin{array}{l}\text { Shopping trip mode choice among } \\
\text { older adults }\end{array}$} \\
\hline & & & $\begin{array}{l}\text { IREM } \\
\text { (raster) }\end{array}$ & $\begin{array}{l}\text { Home location, everyday } \\
\text { destinations, travel routes } \\
\text { (estimated), travel modes, } \\
\text { travel frequency }\end{array}$ & \\
\hline & & & $\begin{array}{l}\text { Circular buffer } \\
\text { (polygon) }\end{array}$ & Home location & \\
\hline \multirow[t]{3}{*}{$\begin{array}{l}\text { (Perchoux et al., } \\
\text { 2014) }\end{array}$} & \multirow[t]{3}{*}{ Paris } & \multirow[t]{3}{*}{$\begin{array}{l}\text { Online } \\
(2062)\end{array}$} & $\begin{array}{l}\text { SDE } \\
\text { (polygon) }\end{array}$ & $\begin{array}{l}\text { Home location, secondary place } \\
\text { of residence, workplace, } \\
\text { everyday errand points }\end{array}$ & \multirow{3}{*}{$\begin{array}{l}\text { Assessment of spatial behavior } \\
\text { patterns in health studies- } \\
\text { associations with sociodemographic } \\
\text { characteristics and transportation } \\
\text { modes }\end{array}$} \\
\hline & & & $\begin{array}{l}\text { Convex hull } \\
\text { (polygon) }\end{array}$ & $\begin{array}{l}\text { Home location, secondary place } \\
\text { of residence, workplace, } \\
\text { everyday errand points }\end{array}$ & \\
\hline & & & $\begin{array}{l}\text { Perceived } \\
\text { residential } \\
\text { neighborhood } \\
\text { (polygon) }\end{array}$ & $\begin{array}{l}\text { Perceived residential } \\
\text { neighborhood boundaries }\end{array}$ & \\
\hline \multirow[t]{3}{*}{$\begin{array}{l}\text { (Laatikainen } \\
\text { et al., 2018) }\end{array}$} & \multirow[t]{3}{*}{ HMA } & \multirow[t]{3}{*}{$\begin{array}{l}\text { Online } \\
(844)\end{array}$} & $\begin{array}{l}\text { High exposure } \\
\text { areas } \\
\text { (polygon) }\end{array}$ & $\begin{array}{l}\text { Home location, everyday } \\
\text { destinations, travel mode, } \\
\text { travel routes (estimated), } \\
\text { travel frequency }\end{array}$ & \multirow[t]{3}{*}{$\begin{array}{l}\text { A comparison of different activity } \\
\text { space models and their implications } \\
\text { for environmental health promotion } \\
\text { research }\end{array}$} \\
\hline & & & $\begin{array}{l}\text { Circular buffer } \\
\text { (polygon) }\end{array}$ & Home location & \\
\hline & & & $\begin{array}{l}\text { Home range } \\
\text { (polygon) }\end{array}$ & $\begin{array}{l}\text { Home location, everyday } \\
\text { destinations, travel mode, } \\
\text { travel routes (estimated) }\end{array}$ & \\
\hline $\begin{array}{l}\text { (Shareck et al., } \\
\text { 2013) }\end{array}$ & Montreal & $\begin{array}{l}\text { Online } \\
(844)\end{array}$ & $\begin{array}{l}\text { Convex hull } \\
\text { (polygon) }\end{array}$ & $\begin{array}{l}\text { Regularly visited activity } \\
\text { locations }\end{array}$ & $\begin{array}{l}\text { Examining the spatial congruence } \\
\text { between survey-based and GPS- } \\
\text { based activity spaces }\end{array}$ \\
\hline $\begin{array}{l}\text { (Kyttä et al., } \\
\text { 2015a, 2015b) }\end{array}$ & HMA & $\begin{array}{l}\text { Online } \\
(3119)\end{array}$ & $\begin{array}{l}\text { Circular buffer } \\
\text { (polygon) }\end{array}$ & Home location & $\begin{array}{l}\text { Examining the effects of urban } \\
\text { settings on social sustainability }\end{array}$ \\
\hline
\end{tabular}

HMA Helsinki metropolitan area, Finland-Paris, France-Tampere, Finland-Alexandria, Egypt-Montreal, Canada

*Additional attribute data was collected online 
It is noteworthy that there are also other studies in which activity spaces are not explicitly delineated; however, their various characteristics are measured through PPGIS data. Examples of this include multiple studies on the distribution of everyday important places and the dispersion of activity spaces using measures such as the centricity index (Hasanzadeh, 2019c; Hasanzadeh et al., 2021; Kajosaari et al., 2020; Ramezani et al., 2019, 2021).

The growing use of PPGIS methods for studying activity spaces may suggest that PPGIS can be considered a promising alternative data collection method for such studies. However, like any scientific method, PPGIS has both advantages and disadvantages. Table 3 presents a summary of the pros and cons of using PPGIS methods for modeling activity spaces.

A major starting point of PPGIS methodology and an important factor in its popularity over the years is its ability to link people with places and human experiences with spatial expressions in ways that are relevant to many research fields (Kahila \& Kyttä, 2009; Kyttä et al., 2013). With PPGIS, various attribute data can be linked to places, resulting in spatial data layers that can create new analytical possibilities and provide opportunities to investigate human-environment relationships in a more individualized and refined manner.

Furthermore, many quantitative approaches thrive on larger sample sizes. A larger sample size adds to the robustness of many analytical processes and can increase the reliability of the results. This is particularly important in urban and environmental studies, where a more reliable result can mean a greater research impact. While most methods of collecting individualized spatial data are costly and time-consuming, PPGIS methods can provide a feasible and cost-effective way to collect individual-based data. This can greatly enhance participation, as a larger number of participants can be recruited (Brown \&
Fagerholm, 2015; Kyttä \& Kahila, 2011), resulting in larger and more representative datasets (Laatikainen et al., 2015, 2018). However, the quality of PPGIS data is strongly dependent on the sampling design and participation rates (Brown \& Kyttä, 2018). As the participation rate can vary between different social classes and age groups, certain groups may be underor overrepresented in the dataset, resulting in possible biases.

At the same time, a large sample does not necessarily ensure a rich spatial dataset. One limitation to PPGIS data collection methods is that the volume of spatial data (e.g., marked points) is usually smaller compared to more specialized spatial datasets such as those collected via GPS or phone tracking, which provide real-time tracking (Brown \& Kyttä, 2014). The sparsity of data not only poses challenges to the modeling but also can introduce biases, as the volume of information can vary from person to person depending on their engagement in the study, among other reasons (Brown, 2016). However, because of its less complex spatial structure, processing PPGIS data is also considerably easier and requires less geospatial expertise. This is a significant difference from, for example, GPS data, which typically need to undergo deep data cleaning and complex noise reductions (C. $\mathrm{Xu}$ et al., 2010).

As Brown and Pullar argue (2012), the validity of PPGIS methods depends on not only participation rates but also the quality of data collected. Like other GIS data, the quality of the spatial data acquired through PPGIS can be determined by both the precision and the accuracy of the markings. Precision is a measure of the exactness of marking placement. The precision of PPGIS data depends on a number of variables, including the size of the marker and map scale, as well as participant characteristics such as visual acuity and physical dexterity (Brown, 2012). Accuracy reflects how close the marking is to the true

Table 3 Pros and cons of using PPGIS in activity space studies

\begin{tabular}{ll}
\hline Pros & Cons \\
\hline Data are individualized & Sparse spatial data \\
Data are more feasible to collect and process & Sampling, participation, and data quality issues \\
Data can be collected from larger samples & Variations between individuals \\
There is a better link between person and space & Missing temporal information \\
Attribute data are geocoded &
\end{tabular}


location of the attribute being mapped. Accuracy in PPGIS is influenced by a number of variables, including the nature of the attribute being mapped, the quality of the mapping environment, and respondents' mapping abilities (Brown, 2012). In practice, this means that there is no single answer to "how accurate PPGIS is?", as the accuracy of markings, and hence data, can vary depending on "what is mapped?", "how is it mapped?", and "who is mapping it?".

Nevertheless, a number of studies have empirically evaluated the spatial quality of PPGIS data and have demonstrated that it can be "good enough" for many purposes (Brown, 2012; Brown et al., 2015). In particular, a few studies have empirically evaluated the suitability of PPGIS data for activity space mapping and exposure modeling. Laatikainen and colleagues (2018) show that with the use of the appropriate activity space modeling methods, PPGIS can yield comparable results to those obtained from GPS data. Similarly, other studies show that there is spatial correspondence between destinations collected through online surveys and GPS tracking (Kestens et al., 2018; Shareck et al., 2013). These findings suggest that the two collection methods are congruent and can offer complementary ways to assess daily mobility (Shareck et al., 2013).

Finally, a major limitation of PPGIS data, which has remained unresolved to this point, is the lack of a temporal component (Perchoux et al., 2014). Positional data such as those collected through GPS are accompanied by timestamps capturing the temporal aspect of mobility. Time can be captured through PPGIS methods using self-reported information, which can be too laborious for study participants and unreliable for further analysis (Laatikainen et al., 2018).

\section{Discussion}

The use of activity spaces has been exponentially increasing in different fields of research over the past decades. Whether used as a spatial unit of analysis or a means of measuring individual mobility or exposure, activity spaces provide unique opportunities to investigate human-environment relationships in an individualized and more refined manner. While using PPGIS data for activity space studies can clearly have advantages, it also comes with limitations that need to be taken into consideration. In the following sections, these potentials and limitations will be further discussed.

Connecting people and places

As activity spaces rely on individual-level spatial data, data acquisition for developing them has generally been regarded as costly and time-consuming. The difficulty of data acquisition coupled with the technical difficulties associated with modeling individualized activity spaces could explain why despite the evident advantages, activity spaces are still underused in research. PPGIS methods, particularly map-based surveys, can help ease some of the difficulties related to data collection for modeling and studying activity spaces. As already evident from the many studies using PPGIS for various research purposes, PPGIS can offer an effective way of collecting person-based data while maintaining the links between individuals and their relevant places (Kyttä et al., 2013).

PPGIS can provide spatial data layers that can identify the distribution of a wide range of spatial attributes such as activities, values, and preferences (Brown \& Kyttä, 2014). These spatial attributes can be overlayed with physical GIS data layers to examine the potential spatial associations between individuals, their mapped locations and the physical attributes of the environment. A general research question that can be approached using PPGIS is why different activities happen in various geographic locations. Sometimes, the answer may be obvious, such as a shopping trip to a shopping center. For some other attributes, such as perceived aesthetics, the rationale for placement may be less obvious and hence require deeper analysis and scrutiny (Brown \& Kyttä, 2014).

\section{Feasibility and cost effectiveness}

When evaluating the cost effectiveness of a data collection process, both the time and money allocated are key indicators (Brown \& Fagerholm, 2015). While some PPGIS data collection methods, such as those involving interview campaigns and paper-based surveys, can be very time-consuming, online PPGIS surveys are usually considerably more efficient (Brown \& Fagerholm, 2015). However, there can be other costs involved in PPGIS data collection that can 
greatly vary depending on how the process is implemented and the context in which the data are collected. For example, there can be costs related to the technology used for online data collection, the acquisition of samples, and possible incentives offered to the participants (Brown \& Fagerholm, 2015). Although the cost effectiveness of PPGIS methods can be ambiguous due to the variability of costs, one can easily argue that online PPGIS data collection for large samples is more efficient than, for example, GPS data collection, which requires expensive devices and considerable time for data collection (Wolf et al., 2015).

PPGIS data can be cost effective to collect and relatively convenient to process and use. Although any data needs to undergo comprehensive scrutiny and quality checks prior to use, PPGIS data do not require complicated data cleaning and noise removal procedures, as GPS data do. Additionally, as discussed earlier, collecting spatial attributes is fairly easy in PPGIS surveys, especially online surveys, which eliminate the need for manual digitization. Retrieving such information using other spatial data collection methods is often impractical, if not impossible. For example, the use of diaries, which are common in GPS data collection processes, has been proven to be laborious both for the participants and the researchers who need to digitize and analyze them (Nguyen et al., 2017).

Both quality and quantity matter

As discussed in the previous section, PPGIS can provide a more feasible and cost-effective way of collecting individual-based spatial data. This means that data from larger sample sizes can be collected more effectively, and the increase in data quantity can, in turn, result in more robust statistical analyses. This is one way in which the quantity of data can contribute to the quality of results. Nevertheless, a higher quantity cannot compensate for low quality data (Woodall et al., 2014).

The quality of PPGIS data can be evaluated by examining several aspects. One of these important aspects is the representativeness of the dataset. The quality of PPGIS data is inextricably linked with the sampling design and participation rates (Brown \& Kyttä, 2018). As the participation rate can vary between different social classes and age groups, certain groups may be under- or overrepresented in the dataset, resulting in biased findings. However, the available evidence suggests that under- or overrepresentation of some groups in PPGIS may not be systematic (Brown \& Kyttä, 2014). For instance, in a series of PPGIS studies by Kyttä et al. (2011), middleincome households and middle-aged women were overrepresented in the data, while in a large PPGIS study by Kyttä and her colleagues (2013), only the oldest age group and single households were slightly overrepresented. However, these findings may not be universal, as map literacy and the ease of use of computers-in the case of online data collection-may vary greatly between different groups and in various societies depending on factors such as education. For example, several studies show that the use of online mapping tools can be particularly problematic for older age groups (Yu \& Chattopadhyay, 2020). Cognitive challenges ranging from a lack of experience to concentration, spatial ability, or memory deficiencies as well as physical limitations such as reduced visual acuity or color vision deficiency may impair the quality of map reading or website experiences (Gottwald et al., 2016; Kovanen et al., 2012). While there are studies showing that the digital divide between different age groups can be managed using the right approaches (Egli et al., 2020; Gottwald et al., 2016; Kytta et al., 2012), we have no reason to believe that such findings are generalizable or universal.

In addition to the representativeness of data, the sufficiency of spatial data for meaningful GIS analysis is another important metric for the quality of PPGIS data (Brown \& Kyttä, 2018). A common limitation of PPGIS data is that the volume of spatial data is usually smaller compared to datasets such as those collected via GPS or phone tracking (Brown \& Kyttä, 2014). The sparsity of spatial data can not only pose challenges to the modeling but also introduce biases to the analysis results, as the volume of information can vary from person to person depending on a number of factors, such as their engagement in the study (Brown, 2016). Because of this individual variability, it is difficult-if not impossible-to interpret the number of markings as a measure of activity or mobility without proper consideration (Kajosaari et al., 2020).

Another concern related to the quality of PPGIS data is the spatial accuracy and precision of mapped features. As spatial information in PPGIS is generated by the participants, very often through non- 
administered processes (Fagerholm et al., 2021), the accuracy and precision of spatial features can vary greatly. However, previous research has shown that the spatial quality of PPGIS data can be sufficient for many purposes (Brown, 2012; Brown et al., 2015), particularly for mapping activity spaces and assessing daily mobility (Kestens et al., 2018; Laatikainen et al., 2018; Shareck et al., 2013).

The missing fourth dimension: time

For over two decades, activity space researchers have increasingly highlighted the importance of the temporal dimension of mobility in activity space modeling and analysis (Newsome et al., 1998). Time is an integral dimension of space, and the spatiotemporal analysis of activity spaces seems to be a promising path for future research (Laatikainen et al., 2018). Acquiring temporal information does not usually require any extra effort when using spatial datasets such as those collected using GPS, mobile phone tracking, or even big data because the spatial features in these datasets are typically accompanied by timestamps, making it easy to extract temporal information from the data. For example, in a travel route obtained from GPS, we normally have the time of data collection at each recorded point along the trajectory.

In contrast, acquiring information on the temporal aspect of mobility is far from easy with PPGIS, as current data collection methods have significant limitations with the acquisition of temporal information. Except in a few cases where PPGIS has been used as a real-time data collection method (Huck et al., 2014), the timestamps of data entry in PPGIS surveys are not meaningful for research. Hence, researchers need to rely on self-reported time, which can be burdensome for the participants and unreliable for use in research. This can explain why activity space research using PPGIS data has virtually never incorporated the temporal dimension in the quantitative analysis. Perhaps the use of frequency of travel (Hasanzadeh et al., 2018; Laatikainen et al., 2018) or the estimation of travel time using route analysis (Hasanzadeh et al., 2018; Saadallah, 2020) have been the closest researchers have come to incorporating time in activity space modeling using PPGIS data. Given such limitations, the advancement of PPGIS data collection techniques, especially as related to incorporating temporal data, is needed to guarantee a spot for PPGIS in future activity space research.

\section{Special considerations for future research}

PPGIS data are not fundamentally different from other sources of spatial data. This means that most GIS analyses, including those related to mapping activity spaces, previously conducted using conventional GIS data can also be conducted with PPGIS data. However, PPGIS data have characteristics that distinguish them in several ways from traditional spatial datasets. These characteristics, which were presented and discussed as pros and cons of PPGIS in this paper, can open new research opportunities but also pose new challenges. However, some of these challenges can be overcome with awareness and the right choice of methods.

As spatial information in PPGIS is user generated, the spatial quality of mapped features can vary greatly. Therefore, it is important to remove any errors in spatial features and check the overall quality of the data. Spatial data quality can, for example, be validated by comparing the position of a random selection of markings with their real known locations (Brown, 2012; Brown et al., 2015). Examples of features that can be used for data quality validation include home locations and well-known landmarks in the study area. Furthermore, the variability of accuracy and precision in a PPGIS dataset, which result from individuals' variable ability in mapping, can pose challenges to geospatial analysis. An earlier study suggests that the undesirable effects resulting from variability in the spatial quality of data can be ameliorated by applying buffers around marked features (Hasanzadeh et al., 2017b). This can reduce the sensitivity of spatial analyses toward such biases.

In addition to the variability between individuals in their mapping abilities, their enthusiasm in doing so can also have an impact on the GIS analysis and any subsequent statistical analyses. For example, an individual who has marked a significantly larger number of activity points in a survey may not necessarily be a more active person; it could merely be that the individual is more enthusiastic about the mapping activity and hence more willing to contribute. In a study by Kajosaari and her colleagues (2019a), the effects of such variability were adjusted in the 
statistical analysis by including the number of markings as a control variable in the regression analysis.

Additionally, the usual sparsity of spatial features in PPGIS data demands the more creative use of GIS techniques for modeling. Previous research shows that both polygon and raster representations of activity spaces using PPGIS are possible when the right modeling techniques are used, and the context is taken into account (Hasanzadeh et al., 2018; Laatikainen et al., 2018). However, as briefly reviewed in this paper, thus far, there have been only a few attempts to use PPGIS data in activity space modeling and analysis. Future research using PPGIS for activity space studies can greatly benefit from more research in this area that tries new modeling and analytical techniques.

All things considered, PPGIS can be regarded as a viable method of data collection for activity spaces that can enable new analytical possibilities and potentially reveal new knowledge. However, some of its characteristics necessitate special analytical considerations. As PPGIS is relatively new in activity space and mobility studies, it presents many shortcomings that require further research.

\section{Conclusions}

PPGIS has emerged as an increasingly popular approach to improve spatial representation. Similar to conventional approaches such as GPS, PPGIS also allows assessment of where people spend time in their everyday environments, albeit with self-reported as opposed to objectively measured locations. Compared to other data collection methods, PPGIS more readily allows for the collection of individual-level information on the whereabouts of individuals and their experiences in their everyday environments.

The use of PPGIS data for activity space studies has several advantages. The potential to have larger samples using PPGIS enables the use of more comprehensive statistical analyses while saving time and money on data collection. Additionally, the strong link maintained between individuals and their places facilitates a more person-based approach to investigating human-environment relationships. At the same time, the use of PPGIS for activity space studies comes with analytical and data quality challenges that need to be carefully taken into consideration. To this point, the use of PPGIS has been rather limited in activity space research. Given its significant potential for new knowledge discovery, its use is expected to grow in this field. However, the existing limitations related to the collection and use of PPGIS data for activity space analysis need to be addressed in future research. In particular, future research needs to seek new ways of effectively incorporating the temporal dimension into PPGIS and find new methods of using these data for activity space modeling and analysis.

Acknowledgements This research is partially funded by Academy of Finland as part of PLANhealth Project (13297753). I would also like to acknowledge FinEst (H2020 grant 856602) for supporting this study. I would like to acknowledge prof. Marketta Kyttä and Dr. Tiina Rinne for their contribution to this research.

Funding Open access funding provided by Aalto University. This research is partially funded by Academy of Finland as part of PLANhealth Project (13297753). The study is also supported by FinEst (H2020 grant 856602 ).

\section{Declarations}

Conflict of interest The authors declare that they have no conflicts of interest.

Human or animal rights This article does not contain any studies involving animals performed by any of the authors. This article does not contain any studies involving human participants performed by any of the authors.

Open Access This article is licensed under a Creative Commons Attribution 4.0 International License, which permits use, sharing, adaptation, distribution and reproduction in any medium or format, as long as you give appropriate credit to the original author(s) and the source, provide a link to the Creative Commons licence, and indicate if changes were made. The images or other third party material in this article are included in the article's Creative Commons licence, unless indicated otherwise in a credit line to the material. If material is not included in the article's Creative Commons licence and your intended use is not permitted by statutory regulation or exceeds the permitted use, you will need to obtain permission directly from the copyright holder. To view a copy of this licence, visit http://creativecommons.org/licenses/by/4.0/.

\section{References}

Babelon, I., Ståhle, A., \& Balfors, B. (2017). Toward cyborg PPGIS: Exploring socio-technical requirements for the use of web-based PPGIS in two municipal planning cases, stockholm region, Sweden. Journal of Environmental Planning and Management, 60(8), 1366-1390. https://doi. org/10.1080/09640568.2016.1221798 
Boone-Heinonen, J., \& Gordon-Larsen, P. (2011). Life stage and sex specificity in relationships between the built and socioeconomic environments and physical activity. Journal of Epidemiology and Community Health, 65(10), 847-852. https://doi.org/10.1136/jech.2009.105064

Broberg, A., \& Sarjala, S. (2015). School travel mode choice and the characteristics of the urban built environment: The case of Helsinki, Finland. Transport Policy, 37, 1-10. https://doi.org/10.1016/J.TRANPOL.2014.10.011

Brown, G. (2012). An empirical evaluation of the spatial accuracy of public participation GIS (PPGIS) data. Applied Geography, 34, 289-294. https://doi.org/10.1016/J. APGEOG.2011.12.004

Brown, G. (2016). A review of sampling effects and response bias in internet participatory mapping (PPGIS/PGIS/VGI). Transactions in GIS. https://doi.org/10.1111/tgis.12207

Brown, G., \& Fagerholm, N. (2015). Empirical PPGIS/PGIS mapping of ecosystem services: A review and evaluation. Ecosystem Services, 13, 119-133. https://doi.org/10.1016/ j.ecoser.2014.10.007

Brown, G., \& Kyttä, M. (2014). Key issues and research priorities for public participation GIS (PPGIS): A synthesis based on empirical research. Applied Geography, 46, 126-136. https://doi.org/10.1016/j.apgeog.2013.11.004

Brown, G., \& Kyttä, M. (2018). Key issues and priorities in participatory mapping: Toward integration or increased specialization? Applied Geography, 95, 1-8. https://doi. org/10.1016/J.APGEOG.2018.04.002

Brown, G., \& Pullar, D. V. (2012). An evaluation of the use of points versus polygons in public participation geographic information systems using quasi-experimental design and monte carlo simulation. International Journal of Geographical Information Science. https://doi.org/10.1080/ 13658816.2011 .585139

Brown, G., Weber, D., \& de Bie, K. (2015). Is PPGIS good enough? An empirical evaluation of the quality of PPGIS crowd-sourced spatial data for conservation planning. Land Use Policy, 43, 228-238. https://doi.org/10.1016/J. LANDUSEPOL.2014.11.014

Buelens, B., Daas, P.J.H., Burger, J., Puts, M., \& van den Brakel, J. (2014). Selectivity of big data. In statistics Netherlands advisory council meeting.

Buliung, R. N., \& Kanaroglou, P. S. (2006). Urban form and household activity-travel behavior. Growth and Change, 37(2), 172-199. https://doi.org/10.1111/j.1468-2257.2006. 00314.x

Burt, W. H. (1943). Territoriality and home range concepts as applied to mammals. Journal of Mammalogy, 24(3), 346-352. https://doi.org/10.2307/1374834

Chainey, S., Tompson, L., \& Uhlig, S. (2008). The utility of hotspot mapping for predicting spatial patterns of crime. Security Journal, 21, 4-28. https://doi.org/10.1057/sj. 2008.6

Chaix, B., Kestens, Y., Perchoux, C., Karusisi, N., Merlo, J., \& Labadi, K. (2012). An interactive mapping tool to assess individual mobility patterns in neighborhood studies. American Journal of Preventive Medicine. https://doi.org/ 10.1016/j.amepre.2012.06.026

Chen, B. Y., Wang, Y., Wang, D., Li, Q., Lam, W. H. K., \& Shaw, S. L. (2018). Understanding the impacts ofhuman mobility on accessibility usingmassivemobile phone tracking data. Annals of the American Association of Geographers. https://doi.org/10.1080/24694452.2017. 1411244

Czepkiewicz, M., Ottelin, J., Ala-Mantila, S., Heinonen, J., Hasanzadeh, K., \& Kyttä, M. (2018). Urban structural and socioeconomic effects on local, national and international travel patterns and greenhouse gas emissions of young adults. Journal of Transport Geography. https://doi.org/10. 1016/j.jtrangeo.2018.02.008

Egli, V., Villanueva, K., Donnellan, N., Mackay, L., Forsyth, E., Zinn, C., et al. (2020). Understanding children's neighbourhood destinations: Presenting the Kids-PoND framework. Children's Geographies, 18(4), 420-434.

Fagerholm, N., Raymond, C. M., Olafsson, A. S., Brown, G., Rinne, T., Hasanzadeh, K., et al. (2021). A methodological framework for analysis of participatory mapping data in research, planning, and management. International Journal of Geographical Information Science. https://doi.org/ 10.1080/13658816.2020.1869747

Gesler, W. M., \& Albert, D. P. (2003). How spatial analysis can be used in medical geography. In Spatial Analysis, GIS and Remote Sensing (pp. 19-46). CRC Press. https://doi.org/10. 1201/B12416-10

González, M. C., Hidalgo, C. A., \& Barabási, A.-L. (2008). Understanding individual human mobility patterns. $\mathrm{Na}$ ture, 453(7196), 779-782. https://doi.org/10.1038/ nature 06958

Gottwald, S., Laatikainen, T. E., \& Kyttä, M. (2016). Exploring the usability of PPGIS among older adults: Challenges and opportunities. International Journal of Geographical Information Science, 30(12), 2321-2338. https://doi.org/ 10.1080/13658816.2016.1170837

Harari, G. M. (2020). A process-oriented approach to respecting privacy in the context of mobile phone tracking. Current Opinion in Psychology. https://doi.org/10.1016/j.copsyc. 2019.09.007

Hasanzadeh, K. (2019b). Exploring centricity of activity spaces: From measurement to the identification of personal and environmental factors. Travel Behaviour and Society, 14, 57-65. https://doi.org/10.1016/J.TBS.2018.10.001

Hasanzadeh, K. (2019c). Exploring centricity of activity spaces: From measurement to the identification of personal and environmental factors. Travel Behaviour and Society. https://doi.org/10.1016/j.tbs.2018.10.001

Hasanzadeh, K., Laatikainen, T. E., \& Kyttä, M. (2018). A place-based model of local activity spaces: Individual place exposure and characteristics. Journal of Geographical Systems, 20(3), 227. https://doi.org/10.1007/s10109017-0264-Z

Hasanzadeh, K., Kyttä, M., \& Brown, G. (2019b). Beyond housing preferences: Urban structure and actualisation of residential area preferences. Urban Science, 3(1), 21. https://doi.org/10.3390/urbansci3010021

Hasanzadeh, K., Kyttä, M., Lilius, J., Ramezani, S., \& Rinne, T. (2021). Centricity and multi-locality of activity spaces: The varying ways young and old adults use neighborhoods and extra-neighborhood spaces in helsinki metropolitan area. Cities. https://doi.org/10.1016/j.cities.2020.103062

Hasanzadeh, K., Broberg, A., \& Kyttä, M. (2017). Where is my neighborhood? A dynamic individual-based definition of home ranges and implementation of multiple evaluation 
criteria. Applied Geography, 84(C), 1-10. https://doi.org/ 10.1016/j.apgeog.2017.04.006

Hasanzadeh, K., Broberg, A., \& Kyttä, M. (2017). Where is my neighborhood? A dynamic individual-based definition of Home zones. Applied Geography, 84(C), 1-10. https://doi. org/10.1016/j.apgeog.2017.04.006

Hasanzadeh, K., Czepkiewicz, M., Heinonen, J., Kyttä, M., AlaMantila, S., \& Ottelin, J. (2019). Beyond geometries of activity spaces: A holistic study of daily travel patterns, individual characteristics, and perceived wellbeing in helsinki metropolitan area. Journal of Transport and Land Use. https://doi.org/10.5198/jtlu.2019.1148

Hasanzadeh, K. (2019a). Spatial units of analysis: Are there better ways? An empirical framework for use of individualized activity space models in environmental health promotion research. Aalto university. Retrieved from http://urn.fi/URN:ISBN:978-952-60-8519-7.

Haybatollahi, M., Czepkiewicz, M., Laatikainen, T. E., \& Kyttä, M. (2015). Neighbourhood preferences, active travel behaviour, and built environment: An exploratory study. Transportation Research Part F Traffic Psychology and Behaviour, 29, 57-69. https://doi.org/10.1016/j.trf.2015. 01.001

Hirsch, J. A., Winters, M., Clarke, P., \& McKay, H. (2014). Generating GPS activity spaces that shed light upon the mobility habits of older adults: A descriptive analysis. International Journal of Health Geographics, 13(1), 51.

Huang, Q., \& Wong, D. W. S. (2015). Modeling and visualizing regular human mobility patterns with uncertainty: An example using twitter data. Annals of the Association of American Geographers. https://doi.org/10.1080/ 00045608.2015.1081120

Huck, J. J., Whyatt, J. D., \& Coulton, P. (2014). Spraycan: A PPGIS for capturing imprecise notions of place. Applied Geography. https://doi.org/10.1016/j.apgeog.2014.09.007

Jagadish, H. V., Gehrke, J., Labrinidis, A., Papakonstantinou, Y., Patel, J. M., Ramakrishnan, R., \& Shahabi, C. (2014). Big data and its technical challenges. Communications of the ACM, 57(7), 86-94.

Kahila, M., \& Kyttä, M. (2009). SoftGIS as a bridge-builder in collaborative urban planning (pp. 389-411). Netherlands: Springer. https://doi.org/10.1007/978-1-4020-8952-7_19

Kahila-Tani, M., Kytta, M., \& Geertman, S. (2019). Does mapping improve public participation? Exploring the pros and cons of using public participation GIS in urban planning practices. Landscape and Urban Planning. https://doi. org/10.1016/j.landurbplan.2019.02.019

Kajosaari, A., Hasanzadeh, K., \& Kyttä, M. (2019a). Residential dissonance and walking for transport. Journal of Transport Geography, 74, 134-144. https://doi.org/10.1016/J. JTRANGEO.2018.11.012

Kajosaari, A., Hasanzadeh, K., \& Kyttä, M. (2019b). Residential dissonance and walking for transport. Journal of Transport Geography. $\quad$ https://doi.org/10.1016/j.jtrangeo.2018.11. 012

Kajosaari, A., Haybatollahi, M., Hasanzadeh, K., \& Kyttä, M. (2020). Examining the effects of residential location and stated residential preferences on activity space size and centricity. Travel Behaviour and Society. https://doi.org/ 10.1016/j.tbs.2020.11.002
Kestens, Y., Lebel, A., Daniel, M., Thériault, M., \& Pampalon, R. (2010). Using experienced activity spaces to measure foodscape exposure. Health \& Place, 16(6), 1094-1103. https://doi.org/10.1016/j.healthplace.2010.06.016

Kestens, Y., Lebel, A., Chaix, B., Clary, C., Daniel, M., Pampalon, R., et al. (2012). Association between activity space exposure to food establishments and individual risk of overweight. PLoS ONE, 7(8), e41418. https://doi.org/10. 1371/journal.pone.0041418

Kestens, Y., Thierry, B., Shareck, M., Steinmetz-Wood, M., \& Chaix, B. (2018). Integrating activity spaces in health research: Comparing the VERITAS activity space questionnaire with 7-day GPS tracking and prompted recall. Spatial and Spatio-Temporal Epidemiology, 25, 1-9. https://doi.org/10.1016/J.SSTE.2017.12.003

Kovanen, J., Oksanen, J., Sarjakoski, L., \& Sarjakoski, T. (2012). Simple maps-a concept of plain cartography within a mobile context for elderly users. In proceedings of the GIS research UK 20th annual conference.

Kyttä, M., \& Kahila, M. (2011). SoftGIS methodology-building bridges in urban planning. GIM International (The Global Magazine for Geomatics), 25(3), 37-41.

Kyttä, M., Kahila, M., \& Broberg, A. (2011). Perceived environmental quality as an input to urban infill policy-making. Urban Design International. https://doi.org/10.1057/udi. 2010.19

Kyttä, M., Broberg, A., Tzoulas, T., \& Snabb, K. (2013). Towards contextually sensitive urban densification: Location-based softGIS knowledge revealing perceived residential environmental quality. Landscape and Urban Planning, $\quad 113, \quad 30-46 . \quad$ https://doi.org/10.1016/j. landurbplan.2013.01.008

Kyttä, M., Broberg, A., Haybatollahi, M., \& Schmidt-Thome, K. (2015a). Urban happiness: Context-sensitive study of the social sustainability of urban settings. Environment and Planning B Planning and Design, 43(1), 34-57. https://doi. org/10.1177/0265813515600121

Kyttä, M., Broberg, A., Haybatollahi, M., Schmidt-Thomé, K., \& Schmidt-Thome, K. (2015b). Urban happiness: Contextsensitive study of the social sustainability of urban settings. Environment and Planning B Planning and Design, 43(1), 34-57. https://doi.org/10.1177/0265813515600121

Kytta, A. M., Broberg, A. K., \& Kahila, M. H. (2012). Urban environment and children's active lifestyle: Softgis revealing children's behavioral patterns and meaningful places. American Journal of Health Promotion. https://doi. org/10.4278/ajhp.100914-QUAN-310

Laatikainen, T. E., Tenkanen, H., Kyttä, M., \& Toivonen, T. (2015). Comparing conventional and PPGIS approaches in measuring equality of access to urban aquatic environments. Landscape and Urban Planning, 144, 22-33. https://doi.org/10.1016/J.LANDURBPLAN.2015.08.004

Laatikainen, T. E., Hasanzadeh, K., \& Kyttä, M. (2018). Capturing exposure in environmental health research: Challenges and opportunities of different activity space models. International Journal of Health Geographics, 17(1), 29. https://doi.org/10.1186/s12942-018-0149-5

Laatikainen, T. E., Haybatollahi, M., \& Kyttä, M. (2019). Environmental, individual and personal goal influences on older adults' walking in the helsinki metropolitan area. International Journal of Environmental Research and 
Public Health, 16(1), 58. https://doi.org/10.3390/ ijerph16010058

Matthews, S. A. (2011). Spatial polygamy and the heterogeneity of place: Studying people and place via egocentric methods. Communities Neighborhoods and Health Expanding the Boundaries of Place. https://doi.org/10.1007/978-14419-7482-2

Mavoa, S., Oliver, M., Witten, K., \& Badland, H. (2011). Linking GPS and travel diary data using sequence alignment in a study of children's independent mobility. International Journal of Health Geographics, 10(1), 64. https:// doi.org/10.1186/1476-072X-10-64

Mavoa, S., Bagheri, N., Koohsari, M. J., Kaczynski, A. T., Lamb, K. E., Oka, K., et al. (2019). How do neighbourhood definitions influence the associations between built environment and physical activity? International Journal of Environmental Research and Public Health. https://doi. org/10.3390/ijerph16091501

Munro, J., Pearce, J., Brown, G., Kobryn, H., \& Moore, S. A. (2017). Identifying 'public values' for marine and coastal planning: Are residents and non-residents really so different? Ocean \& Coastal Management, 148, 9-21. https://doi. org/10.1016/J.OCECOAMAN.2017.07.016

Newsome, T. H., Walcott, W. A., \& Smith, P. D. (1998). Urban activity spaces: Illustrations and application of a conceptual model for integrating the time and space dimensions. Transportation, 25(4), 357-377. https://doi.org/10.1023/ A: 1005082827030

Nguyen, T.T., Armoogum, J., Madre, J.L., \& Pham, T.H. T. (2017). GPS and travel diary: Two recordings of the same mobility, $13 \mathrm{p}$. https://hal.archives-ouvertes.fr/hal01588420/. Accessed 30 November 2018

Obermeyer, N. J. (1998). Evolution of public participation GIS. Cartography and Geographic Information Systems. https:// doi.org/10.1559/152304098782594599

Perchoux, C., Kestens, Y., Thomas, F., Hulst, A. V., Thierry, B., \& Chaix, B. (2014). Assessing patterns of spatial behavior in health studies: Their socio-demographic determinants and associations with transportation modes (the RECORD cohort study). Social Science and Medicine, 119, 64-73. https://doi.org/10.1016/j.socscimed.2014.07.026

Perchoux, C., Chaix, B., Brondeel, R., \& Kestens, Y. (2016). Residential buffer, perceived neighborhood, and individual activity space: New refinements in the definition of exposure areas-The RECORD Cohort Study. Health and Place, 40, 116-122. https://doi.org/10.1016/j.healthplace.2016. 05.004

Perchoux, C., Brondeel, R., Wasfi, R., Klein, O., Caruso, G., Vallée, J., et al. (2019). Walking, trip purpose, and exposure to multiple environments: A case study of older adults in luxembourg. Journal of Transport and Health. https:// doi.org/10.1016/j.jth.2019.04.002

Pesola, A. J., Hakala, P., Berg, P., Ramezani, S., Villanueva, K., Tuuva-Hongisto, S., et al. (2020). Does free public transit increase physical activity and independent mobility in children? Study protocol for comparing children's activity between two Finnish towns with and without free public transit. BMC Public Health, 20(1), 1-10. https://doi.org/10. 1186/s12889-020-8385-6

Ramezani, S., Laatikainen, T., Hasanzadeh, K., \& Kyttä, M. (2019). Shopping trip mode choice of older adults: An application of activity space and hybrid choice models in understanding the effects of built environment and personal goals. Transportation. https://doi.org/10.1007/ s11116-019-10065-z

Ramezani, S., Hasanzadeh, K., Rinne, T., Kajosaari, A., \& Kyttä, M. (2021). Residential relocation and travel behavior change: Investigating the effects of changes in the built environment, activity space dispersion car and bike ownership, and travel attitudes. Transportation Research Part A Policy and Practice. https://doi.org/10.1016/j.tra. 2021.02.016

Reynolds, D. R., \& Horton, F. E. (1971). Effects of urban spatial structure on individual behavior. Economic Geography, 47(1), 36-48. https://doi.org/10.1126/science.11.277.620

Saadallah, D. M. (2020). Utilizing participatory mapping and PPGIS to examine the activities of local communities. Alexandria Engineering Journal, 59(1), 263-274. https:// doi.org/10.1016/j.aej.2019.12.038

Schlossberg, M., \& Shuford, E. (2005). Delineating "public" and "participation" in PPGIS. URISA Journal, 16(2), $15-26$.

Schönfelder, S., \& Axhausen, K. W. (2003). Activity spaces: Measures of social exclusion? Transport Policy, 10(4), 273-286. https://doi.org/10.1016/j.tranpol.2003.07.002

Schuurman, N. (2004). GIS: a short introduction. Blackwell Oxford.

Shareck, M., Kestens, Y., \& Gauvin, L. (2013). Examining the spatial congruence between data obtained with a novel activity location questionnaire, continuous GPS tracking, and prompted recall surveys. International Journal of Health Geographics. https://doi.org/10.1186/1476-072X$12-40$

Sherman, J. E., Spencer, J., Preisser, J. S., Gesler, W. M., \& Arcury, T. A. (2005). A suite of methods for representing activity space in a healthcare accessibility study. International Journal of Health Geographics, 4(1), 24. https://doi. org/10.1186/1476-072X-4-24

Smith, M., Cui, J., Ikeda, E., Mavoa, S., Hasanzadeh, K., Zhao, J., et al. (2021). Objective measurement of children's physical activity geographies: A systematic search and scoping review. Health and Place. https://doi.org/10.1016/ j.healthplace.2020.102489

Torralba, M., Fagerholm, N., Hartel, T., Moreno, G., \& Plieninger, T. (2018). A social-ecological analysis of ecosystem services supply and trade-offs in European woodpastures. Science Advances, 4(5), eaar2176. https://doi.org/ 10.1126/sciadv.aar2176

Vallée, J., Cadot, E., Roustit, C., Parizot, I., \& Chauvin, P. (2011). The role of daily mobility in mental health inequalities: The interactive influence of activity space and neighbourhood of residence on depression. Social Science and Medicine, 73(8), 1133-1144. https://doi.org/10.1016/j. socscimed.2011.08.009

Villanueva, K., Giles-Corti, B., Bulsara, M., McCormack, G. R., Timperio, A., Middleton, N., et al. (2012). How far do children travel from their homes? Exploring children's activity spaces in their neighborhood. Health and Place. https://doi.org/10.1016/j.healthplace.2011.09.019

Wang, J., Kwan, M.-P., \& Chai, Y. (2018). An innovative context-based crystal-growth activity space method for environmental exposure assessment: A study using GIS 
and GPS trajectory data collected in Chicago. International Journal of Environmental Research and Public Health, 15(4), 703. https://doi.org/10.3390/ijerph15040703

Wei, Q., She, J., Zhang, S., \& Ma, J. (2018). Using individual gps trajectories to explore foodscape exposure: A case study in Beijing metropolitan area. International Journal of Environmental Research and Public Health. https://doi. org/10.3390/ijerph15030405

Wolf, J., Guensler, R., \& Bachman, W. (2001). Elimination of the travel diary: Experiment to derive trip purpose from global positioning system travel data. Transportation Research Record Journal of the Transportation Research Board, 1768(1), 125-134. https://doi.org/10.3141/1768-15

Wolf, I. D., Wohlfart, T., Brown, G., \& Bartolomé Lasa, A. (2015). The use of public participation GIS (PPGIS) for park visitor management: A case study of mountain biking. Tourism Management, 51, 112-130. https://doi.org/10. 1016/j.tourman.2015.05.003

Wong, D. W. S. S., \& Shaw, S.-L.L. (2011). Measuring segregation: An activity space approach. Journal of Geographical Systems, 13(2), 127-145. https://doi.org/10. 1007/s10109-010-0112-x

Woodall, P., Borek, A., Gao, J., Oberhofer, M. A., \& Koronios, A. (2014). An investigation of how data quality is affected by dataset size in the context of big data analytics. In ICIQ.
Xu, Y., Shaw, S.-L., Zhao, Z., Yin, L., Lu, F., Chen, J., et al. (2016). Another tale of two cities: Understanding human activity space using actively tracked cellphone location data. Annals of the American Association of Geographers, 106(2), 489-502. https://doi.org/10.1080/00045608.2015. 1120147

Xu, C., Ji, M., Chen, W., \& Zhang, Z. (2010). Identifying travel mode from GPS trajectories through fuzzy pattern recognition. In 2010 seventh international conference on fuzzy systems and knowledge discovery. IEEE. pp. 889-893. Doi: https://doi.org/10.1109/FSKD.2010.5569105.

Yu, J.E., \& Chattopadhyay, D. (2020). "Maps are hard for me": Identifying how older adults struggle with mobile maps. In the 22nd international ACM SIGACCESS conference on computers and accessibility pp. 1-8.

Zenk, S. N., Schulz, A. J., Matthews, S. A., Odoms-Young, A., Wilbur, J., Wegrzyn, L., et al. (2011). Activity space environment and dietary and physical activity behaviors: A pilot study. Health and Place, 17(5), 1150-1161. https:// doi.org/10.1016/j.healthplace.2011.05.001

Publisher's Note Springer Nature remains neutral with regard to jurisdictional claims in published maps and institutional affiliations. 